\title{
The Role of Integrated Schools in Improving Islamic Education in Muslim Minority Areas of Cambodia
}

\author{
*Wien Anisa Yahyani ${ }^{1}$, Rido Kurnianto ${ }^{2}$, Ayok Ariyanto ${ }^{3}$ \\ ${ }^{1,2,3}$ Universitas Muhammadiyah Ponorogo, J1. Budi Utomo, No.10, East Java, Indonesia \\ *wienanisa7@gmail.com
}

\begin{abstract}
This study aims to find out how to improve Islamic religious education in the Krouch Chmar area, Cambodia where this area is an Islamic village in the middle of Cambodia, which is a majority Buddhist community, then the Musa Asih Integrated School (SEPAMA) is present which has a role in helping increase in Islamic education. This research uses qualitative methods, data collection using observation, interviews and documentation, qualitative data analysis is carried out continuously to completion. The findings of this researcher are that Islamic religious education in the Krouch Chmar area began to develop with the existence of an integrated school system where this school has a combination of curriculum, namely the national curriculum and the Islamic religious education curriculum, through this school finally Islamic religious education begins to increase because children and the community can easily learn Islamic religious education, this is supported by programs owned by SEPAMA, so that from this school it provides a role in improving Islamic religious education in Islamic minority areas in Cambodia, starting from a pedagogical role, a moralspiritual role and a socio- culture which ultimately improves Islamic religious education in the area.
\end{abstract}

Penelitian ini bertujuan untuk mengetahui bagaimana peningkatan pendidikan agama Islam di daerah Krouch Chmar, Kamboja dimana daerah ini adalah perkampungan Islam yang berada ditengah-tengah Negara Kamboja yang mayoritas masyarakat pemeluk agama Budha, kemudian hadirlah Sekolah Bersepadu Musa Asih (SEPAMA) yang memiliki peran dalam membantu peningkatan pedidikan agama Islam. Penelitian ini menggunakan metode kualitatif, pengumpulan data menggunakan observasi, wawancara dan dokumentasi, analisis data kualitatif ini dilakukan secara terus menerus sampai tuntas. Hasil temuan peneliti ini adalah pendidikan agama Islam di daerah Krouch Chmar mulai berkembang dengan adanya sekolah bersistem integrasi dimana sekolah ini memiliki perpaduan kurikulum yaitu kurikulum kebangsaan dan kurikulum Pendidikan agama Islam, melalui sekolah ini akhirnya Pendidikan agama Islam mulai meningkat karena anak-anak dan masyarakat dapat dengan mudah belajar pendidikan agama Islam, hal ini didukung dengan program-program yang dimiliki oleh SEPAMA, sehingga dari sekolah ini memberikan peran dalam meningkatkan Pendidikan agama Islam di daerah minoritas Islam di Kamboja, mulai dari peran pedagogis, peran moral-spiritual dan peran sosio-kultural yang akhirnya meningkatkan pendidikan agama Islam di daerah tersebut.

Keywords: Role of Schools, Improvement, Islamic Religious Education.

Received: November 14, 2020; Revised: November 26, 2020; Accepted: November 27, 2020 


\section{INTRODUCTION}

School is a means used to transfer knowledge to students (Putri \& Imron, 2019), in Arabic it is called Madrasatun, the school stands as an educational institution that has a system, discipline and components that must be owned, such as buildings that will be used as classrooms (Ariyanto \& Sulistyorini, 2020), teachers as teacher and facilitator of children in learning, as well as the presence of students is an important component in a school (Ariyanto \& Laksana, 2017; Sulistiyana et al., 2019). The existence of a school does not only stand for the students or teachers in it but also stands to foster the community around the school, starting from coaching about life, religion and often through schools, religion is widespread (Syam et al., 2019). The implementation of Islamic education in its application and teaching needs the support of madrasah or school educational institutions so that the presence of Islamic schools today can be an intermediary and in improving Islamic education to the community (Syam \& Arifin, 2018).

Indonesia is a country with the majority of the population being Muslim, this can be seen from the number of Islamic schools that are developing more rapidly than other schools (Kurnianto \& Lestarini, 2020), this is because Islamic schools have a complete package with a balanced curriculum program where $50 \%$ of the general education curriculum and $50 \%$ of the Islamic religious education curriculum is given to all students with unquestionable results (Kurnianto, 2019). An attractive education system like this is what makes Islam the most developed religion in Indonesia, this is evidenced by the presence of pesantren in Indonesia, where currently pesantren have tremendous interest (Budiman, 2017). Based on the latest data, the number of pesantren that have emerged in Indonesia has reached 14,798 pesantren with 3,464,334 students, where each year has increased which show that pesantren have a lot of enthusiasts and can compete with other public schools. This has also made Islamic religious education in Indonesia develop rapidly, with the support of Islamic schools that have sprung up with good packaging and gained the trust of the wider community, which has led to the development of Islamic religious education becoming known and more easily understood by the wider community (Ashari et al., 2017).

In contrast to other countries around Indonesia, such as Cambodia where this country clearly has a different system and governance management from Indonesia as well as education in Cambodia, Islam is a minority religion that is present in the midst of Buddhism which is growing in number. The majority of the Cambodian population is Buddhist, there are no valid statistical data to write down the number of Muslims in Cambodia but it can be estimated that the number is not more than 1 million Muslims or Cham-Jva out of 14 million Cambodians, out of 454 villages in Cambodia. It is estimated that the population of Islam or Cham-Jva is around 450,000 to 500,000 people.

The country of Cambodia has Islamic villages that began to appear in 1993 where this shows that the spread of Islam began to exist but has not been able to develop completely and optimally due to the absence of a proper system to use. Islamic religious education also has not developed rapidly because there is no support for the existence of Islamic religious education in Cambodia, until finally in 2012 there was a school, namely the Musa Asiah Integrated School (SEPAMA) which taught Islamic religious education to the Muslim community through schools, because in 2012 In Cambodia there is a national school that comes with support from the government where the 
curriculum is not allowed to include religious education in it, so before the presence of SEPAMA the Muslim community had to find a place to get Islamic religious education, therefore SEPAMA has a role in improving Islamic religious education in the country of Cambodia.

The facts above show how hard Islamic religious education is in an environment where the majority of people are Non-Muslim. Therefore, the existence of the Musa Asiah Integrated School in the Svay Khleang Krouch Chmar Cambodia area has a very big role in presenting and introducing Islamic religious education in the area, this is what makes this problem quite interesting to be addressed and further reviewed.

\section{METHOD}

The problem of the role of the Musa Asiah Bersepadu school was researched using qualitative research methods to present real events that occurred on the object of research. The main data source in this study was obtained from interviews addressed to the founder of the Musa Asiah Integrated School (SEPAMA) Svay Khleang, Krouch Chmar, Cambodia regarding how the origin of Islamic religious education that was present in Cambodia and the Krouch Chmar region in particular, then the deputy head of the school who explained the role of SEPAMA in implementing efforts to improve Islamic religious education, as well as teachers and the community around SEPAMA to obtain data on how SEPAMA's role is perceived by the community and how teachers view it to determine the extent of SEPAMA's role in improving Islamic religious education. Besides that, it also uses the results of observations made in SEPAMA as well as some documentation related to data presentation.

\section{RESULT AND DISCUSSION}

Islamic schools have a very visible role, especially in being able to teach and spread Islamic religious education to the community, especially if this Islamic school is established in an area that has a small Muslim population (Manira et al., 2019). Cambodia is a country where the majority of the population is non-Muslim so it is clear that Islam has not become a minority in the country so starting from education, places of worship and other things have not become a priority that must be fulfilled or prioritized, this moves a young Muslim in the Svay Khleang area , Krouch Chmar, Cambodia moved to establish an Islamic school that has an integrated system where in this school Muslim children and the community can learn and get to know better Islamic religious education, this school is called Sekolah Bersepadu Musa Asiah or what is often called SEPAMA.

This established Islamic school can support the improvement of Islamic religious education because its existence can meet three aspects that measure the role of Islamic schools in improving Islamic religious education, namely:

\section{Pedagogical Aspects}

Pedagogy or what is often known as education is an important point of the goal of the establishment of the school because through the school any knowledge will be transferred from teachers to students (Katni \& Laksana, 2020; Wekke, 2013). Sekolah Bersepadu Musa Asiah has a program that is carefully selected and arranged to channel good Islamic religious education to the Muslim community in the Svay Khelang Krouch 
Chmar Cambodia area which is an integration program, where in this integration program SEPAMA uses a balanced Kuri-kulum unity of $50 \%$ national curriculum and $50 \%$ percent of the national curriculum, can be explained from the SEPAMA curriculum chart image below:

Table 1.

Integration Curriculum Table

\begin{tabular}{llll}
\multicolumn{1}{c}{ Dual Program } & Syllabus & $\begin{array}{c}\text { Language of } \\
\text { Instruction of } \\
\text { SEPAMA (Low } \\
\text { Level) }\end{array}$ & $\begin{array}{c}\text { Language of } \\
\text { Instruction } \\
\text { SEPAMA (Middle } \\
\text { School) }\end{array}$ \\
\hline $\begin{array}{l}\text { Cambodian National } \\
\text { Curriculum }\end{array}$ & Cambodia & Khmer & Khmer \\
\hline $\begin{array}{l}\text { Islamic Religious } \\
\text { Curriculum }\end{array}$ & $\begin{array}{l}\text { JAKIM } \\
\text { (Malaysian) }\end{array}$ & Melayu (Jawi) & Arabic
\end{tabular}

The integrated curriculum which presents a strong blend of Islamic religious education and national education is given to students, where this can illustrate that SEPAMA has a role in improving Islamic religious education, where through SEPAMA the Muslim community in Svay Khleang Krouch Chmar can study Islamic religious education well, this is in accordance with the theory put forward by Arief Efendi where Islamic schools play a role in shaping and giving birth to a generation of Muslims who are stable in terms of scholarship and complete Islamic insight (Efendi, 2008).

\section{Socio-Cultural Aspects}

The Socio-Cultural Aspect is the role of Islamic schools that give colour to Islam in the midst of people's lives (Suprayitno et al., 2018), where SEPAMA gives a distinctive colour to the area of Svay Khlenag Krouch Chmar, through SEPAMA the community begins to recognize how to dress properly according to Islamic principles, this is also exemplified directly by teachers at SEPAMA who in their daily life always wear the hijab as one of the obligations of a Muslim woman to cover her genitals using a headscarf. This is supported by the habits of teachers in SEPAMA who exemplify the public how to dress well in Islam, starting from the SEPAMA Ustadzah who always wear the hijab wherever they are then the teachers who always maintain good manners with the whole community, which eventually becomes uswah hasanah for Muslims in Krouch Chmar, then supported by one of the programs owned by SEPAMA, namely the night study, in which there is a material taken, namely siroh nabawiyah where through this material the Muslim community of Krouch Chmar knows human role models to live life, namely the prophets who have stories of their life journey. exemplary for all Muslims. This is in accordance with Arief Efendi's theory which says that Islamic schools play a role in improving Islamic religious education in providing a major influence on social life in an area, such as the Musa Asiah Integrated School which provides a good Islamic style (Efendi, 2008).

\section{Moral-Spiritual Aspects}

The Moral-Spiritual aspect is the role of Islamic schools to invite and teach students and the community to know Islam more deeply, love Allah wholeheartedly so that they can worship well. SEPAMA has a program that is taken to help the community and their students to become stable Muslims, this program is a night study in which the Muslim community of Krouch Chmar is invited to learn three discussions, namely: 
1) Al-Qur'an is the holy book of Islam, in which there are all sources of Islamic teachings ranging from science, laws of life, and so on (Laila, 2014). By studying the Qur'an, the Muslim community in Krouch Chmar became proficient in reading the Qur'an and was able to teach it to other Muslims (Marzuki \& Norkhair, 2017).

2) Fiqh science is the science that contains the guidelines for a Muslim's life, starting from how to pray, perform ablution, give zakat, have hajj and even socialize (Mudawam, 2012). This is what makes SEPAMA teach Fiqh to the Islamic community in Cambodia so that Muslims have provisions to worship well (Musa, 2013).

3) Siroh Nabawiyah is a collection of stories of the prophets, who can become inspiration and role models for Muslims in their behavior (Lutfani, 2020), We can take the example of the story of the prophet Muhammad SAW, who in the course of his life there were many role models that should be emulated as a Muslim. This is what makes SEPAMA teach this to the Muslim community there so that later Muslims can live a better life (Musa, 2020).

So that these three materials were chosen by SEPAMA to improve Islamic religious education in the krouch Chmar Cambodia area, this is also in accordance with Arief Efendi's theory which says that Islamic schools can play a role in improving Islamic religious education, namely forming Muslims who have a high love for Islam so that able to fight, move and spread Islam wholeheartedly (Efendi, 2008). In improving Islamic religious education, Islamic schools have a role in making it happen, because through Islamic schools such as SEPAMA in Krouch Chmar, Cambodia has a comprehensive role starting in terms of education, spirituality and also cultural influences.

\section{CONCLUSION}

The existence of the Musa Asiah Bersepadu school has become an important history for the foundation of Islamic education in the Svay Khleang area, Krouch Chmar Cambodia. The position of this school is increasingly convincing that this school has a major role in improving Islamic religious education, in line with the various roles it plays in improving the quality of Islamic religious education in this Muslim minority community, both through formal and non-formal education. The improvement of Islamic education that has been successfully played by this school includes pedagogical, socio-cultural, and moral-spiritual aspects.

First, the pedagogical aspect, where in terms of education there is a marked increase in which students in SEPAMA get a complete and maximum education starting from national education and Islamic religious education, this is supported by the curriculum that has been implemented by SEPAMA; second, the socio-cultural aspect, where in this aspect Islamic schools have a role in improving Islamic religious education as evidenced by the cultural influence that is colored by Islamic religious teachings such as dressing modestly, women covering their genitals then manners that are applied in socializing and socializing. society, where this can be seen from the state of the Krouch Chmar community, which is currently the Muslim community starting to live with a good lifestyle such as a culture of greeting each other, speaking politely and Muslim women who have started to continously wearing clothes and headscarves in accordance with the teachings of Islam; and third, the Moral-Spiritual Aspect in which Islamic 
religious education looks well developed where the Muslim population in Cambodia is very enthusiastic and enthusiastic about learning Islam, through one of the programs held, namely a night study containing material on the Qur'an, Siroh Nabawiyah. and Fiqh through which this program has increased Islamic religious education in krouch Chmar Cambodia.

\section{REFERENCES}

[1] Ariyanto, A., \& Laksana, S. D. (2017). PEMBELAJARAN IPS DENGAN MEDIA KOMIK STRIP DI KELAS 4. Muaddib: Studi Kependidikan Dan Keislaman, 7(2), 188-198.

[2] Ariyanto, A., \& Sulistyorini, S. (2020). Konsep motivasi dasar dan aplikasi dalam lembaga pendidikan Islam. AL-ASASIYYA: Journal Of Basic Education, 4(2), $103-$ 114.

[3] Ashari, R., Syam, A. R., \& Budiman, A. (2017). The World Challenge Of Islamic Education Toward Human Resources Development. Proceeding International Conference on Islamic Education (ICIED), 169-175. http://conferences.uinmalang.ac.id/index.php/icied/article/view/451

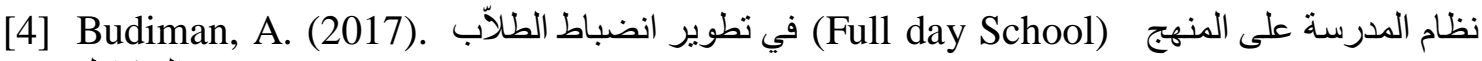
المتكامل. Educan: Jurnal Pendidikan Islam, 1(2).

[5] Efendi, A. (2008). Peran Strategis Lembaga Pendidikan Berbasis Islam di Indonesia. El Tarbawi, 1(1), 1-12.

[6] Katni, K., \& Laksana, S. D. (2020). Model Manajemen Pendidikan Adab Anak Usia Pendidikan Dasar DI MIN Demangan Madiun Jawa Timur Indonesia. $A L$ MURABBI: Jurnal Studi Kependidikan Dan Keislaman, 6(2), 117-129.

[7] Kurnianto, R. (2019). Pembelajaran Agama Islam Berbasis Budaya Lokal (Strategi Internalisasi Nilai-Nilai Pendidikan Agama Islam Melalui Seni Reyog Ponorogo). Seminar Nasional Pendidikan 2015, 862-875.

[8] Kurnianto, R., \& Lestarini, N. (2020). INTEGRATION OF LOCAL WISDOM IN EDUCATION. INTERNATIONAL SEMINAR ON EDUCATION, 557-563.

[9] Laila, I. (2014). Penafsiran Al-Qur'an Berbasis Ilmu Pengetahuan. Epistemé: Jurnal Pengembangan Ilmu Keislaman, 9(1), 45-66.

[10]Lutfani, L. (2020). KONTEKSTUALISASI PENDIDIKAN ISLAM BERBASIS AL-QUR'AN DAN SIRAH NABAWIYAH DALAM SISTEM PENDIDIKAN DI INDONESIA. Al-Munqidz: Jurnal Kajian Keislaman, 8(1), 76-89.

[11] Manira, L., Utari, P., \& Hastjarjo, S. (2019). Cultural Identification and Adaptation of Muslim Minority: Evidence from Cambodia. International Journal of Multicultural and Multireligious Understanding, 6(3), 709-719.

[12] Marzuki, A., \& Norkhair, N. S. (2017). Al-Quran Reading Abilities of Students in Musa-Asiah Integrated School Cambodia. Tinta Artikulasi Membina Ummah, 3(2), 2017.

[13] Moleong, L. J. (2015). Metode Penelitian Kualitatif (Edisi Revisi). Bandung: Remaja Rosdakarya. 
[14] Mudawam, S. (2012). Syari'ah-Fiqih-Hukum Islam: Studi tentang Konstruksi Pemikiran Kontemporer. Asy-Syir'ah: Jurnal Ilmu Syari'ah Dan Hukum, 46(2).

[15] Musa, M. Z. (2013). Perkembangan Islam di Asia Tenggara: Kajian Kemboja. Jurnal Salam, 15(2).

[16] Musa, M. Z. (2020). Initiative in Khmer Islam Early Schooling: The Svay Khleang Experience. International Conference on Community Development (ICCD 2020), 448-454.

[17]Putri, L. I., \& Imron, A. (2019). Deradicalization of Religion in Madrasah Ibtidaiyah Through Character Education. 3rd Annual International Seminar and Conference on Global Issues (ISCoGI 2017).

[18] Sugiyono, S. (2015). Metode Penelitian \& Pengembangan (Research and Development). In Bandung: Alfabeta.

[19] Sulistiyana, S., Wiyono, B. B., Imron, A., \& Suriansyah, A. (2019). Total Quality Management Program Specific Guidance and Counselling Services in the State High School. International Journal of Innovation, 5.

[20] Suprayitno, E., Rois, S., Harmanto, B., \& Iman, N. (2018). Character Education Values In Folklores Of Ponorogo And Their Relevance In Teaching Literature. Proceeding Icon-ELite, 1(1), 27-37.

[21] Syam, A. R., \& Arifin, S. (2018). Islamic Educational Institution Policies Based on Creative Economic the Asean Era Economic Community. EDUKASI: Jurnal Pendidikan Islam, 6(1), 049-063. https://staimtulungagung.ac.id/ejournal/index.php/EDUKASI/article/view/307

[22] Syam, A. R., Rohmadi, M., Rusmita, R., Isnaini, K. N., Sulistywati, Z. U. W., Kurniawan, M. G., Efendi, I. S., Vianto, R., Julianto, M., Astomy, A. M. A., \& others. (2019). Time is Learning: Senarai Pemikiran Keguruan, Mendidik dan Mengajar. Universitas Muhammadiyah Ponorogo Press.

[23]Ulfatin, N. (2015). Metode Penelitian Kualitatif di Bidang Pendidikan: Teori dan Aplikasinya. Malang: Media Nusa Creative.

[24] Wekke, I. S. (2013). Lembaga Pendidikan Sebagai Pilar Dakwah di Wilayah Minoritas Muslim. Jurnal Dakwah Alhikmah, 4(2), 93-118. 